\title{
Governance, rational choice and new pu- blic management (npm): a general view (and some critics)
}

\author{
Governança, escolha racional e new public \\ management (npm): uma visão geral (e algumas \\ críticas)
}

Mateus de Oliveira Fornasier ${ }^{1}$

Sabine Franklin ${ }^{2}$

\begin{abstract}
This article aims to study the New Public Management (NPM), one of the main trends associated to neoliberalism. It studies governance to show its general, wider and abstract scope. It also focuses on the Rational Choice as an important theory about governance, a basis for NPM. And it observes the neoliberal foundations of NPM, showing critical aspects of its real practice. Methodology: hypotheticaldeductive method of research, with a qualitative
\end{abstract}

1 Professor do Programa de Pós-Graduação Stricto Sensu (Mestrado e Doutorado) da Universidade Regional do Noroeste do Estado do Rio Grande do Sul (UNIJUI). Doutor em Direito pela Universidade do Vale do Rio dos Sinos (UNISINOS), com pós-doutorado pela University of Westminster (Reino Unido).

2 PhD in Economics at the University of Westminster (Reino Unido). 
and critical approach and bibliographic-documental research technique. As results of this research, we can conclude that: i) the ideological usage of NPM has been expressed in a culture of minimal state and government - but in practice, such culture, when embossing implemented reforms, seldom reverted the role of the state, destroyed social safety nets, and placed the tax burden on the working majority rather than on the wealthy elite; ii) advocates for NPM have Western-shaped minds, generally making erroneous assumptions about institutions and cultures, which may be present in Anglo-American countries, but not in other culturally different ones; iii) in practice, NPM reforms were imposed to low-income countries by donor institutions to adjust their states for good governance - but those reforms did not solve problems with inefficiency and corruption. This work is original and valuable because it shows that even when public policies highlight the importance of less state intervention, solid norms and institutions are always necessary, and because it helps demystifying discourses that simply put that less state/more market politics can be valuable everywhere.

Keywords: governance; Rational Choice Theory; New Public Management; neoliberalism.

Resumo: Este artigo objetiva estudar a New Public Management (NPM), uma das principais tendências associadas ao neoliberalismo. Estuda a governança para mostrar seu escopo mais geral, amplo e abstrato. Também se concentra na Escolha Racional como uma importante teoria sobre governança, uma base para a NPM. Por fim, observa os fundamentos neoliberais da NPM, mostrando alguns aspectos críticos da sua prática real. Metodologia: método de pesquisa hipotético-dedutivo, com abordagem qualitativa e 
crítica e técnica de pesquisa bibliográfico-documental. Como resultados, concluímos que: i) o uso ideológico da NPM tem sido expresso em uma cultura de estado mínimo e governo - mas, na prática, tal cultura, ao modelar reformas, raramente reverteu o papel do Estado, destruiu as redes de segurança social e colocou a carga tributária sobre a maioria que trabalha, e não sobre a elite rica; ii) os defensores da NPM têm mentes ocidentalizadas, geralmente fazendo suposições errôneas sobre instituições e culturas que podem estar presentes em países anglo-americanos, mas não em outros culturalmente diferentes; iii) na prática, as reformas da NPM foram impostas a países de baixa renda por instituições doadoras para ajustar seus estados à boa governança - mas essas reformas não resolveram problemas com ineficiência e corrupção. Este trabalho é original e valoroso ao mostrar que, mesmo quando políticas públicas destacam a importância de menos intervenção estatal, normas e instituições sólidas são sempre necessárias, e porque ajuda a desmitificar discursos que simplesmente colocam que menos Estado/mais mercado pode ser uma valiosa tendência em todos os lugares.

Palavras-chave: governança; Teoria da Escolha Racional; Nova Gestão Pública; neoliberalismo.

\section{Introduction}

The new federal government that started in Brazil in 2019 was elected, among other several plans, promises and ideological lines, because of a very significative series of reforms in economy - being all of them mainly based on privatization, substitution of a social social security system of solidarity/contribution for a capitalization system, shrinkage of the state - "more Brazil, less Brasilia" ("mais 
Brasil, menos Brasilia") was one of the most repeated mottos of its electioneering campaign - in favor of the market, simplification of the taxation system, among others. Of course this is only one contextual change in one country in all the western world - but it can illustrate how governments can still be elected because of an ideological change towards (neo)liberal trends still in 21st century, combined with populist right-wing promises.

It is not a goal of this work to make a moral evaluation of all these aspects, but to analyze one of the main tendencies in governance theory, that seems to create a basis for all those liberal ideas after 20th century: the Rational Choice school of governance, as well as one of its most prolific trends: the New Public Management (NPM) school.

There are important interdisciplinary and social justifications for this study. In first place, for Law studies, this study can show that even when public policies highlight the importance of less state intervention - leaving the individual with a wider margin to act -, solid norms and institutions are always necessary (which involve a strong state in some manner). And it is also important for studies in public management and political science to demystify discourses that simply put that less state/more market politics can be a valuable trend everywhere, just because in some AngloAmerican countries it was well succeeded in a recent past.

The research problem that conduced this work can be written in these terms: which relationships can be identified between the ideas of governance, rational choice and New Public Management (NPM)? As the main hypothesis to that problem, it can be posted that NPM has emerged as a very important trend in public management in the second half of the 20th Century, and it is based in ideas of less state and more market leading in conducing public issues, such as 
services. It has been a response to strategies that supposedly took public managements around the world to a crisis during the 1970s because of the erosion of Welfare State (which was characterized by a very high level of intervention of the State in the Economy and in service offering, among other things), highly influenced by rational choice theory - which, by its turn, was created in the intersection between Political studies and Economy. However, although the idea of governance was spread around the world in consonance with the ideas of NPM, the first one is a much more abstract and wider idea that simply rational choice, neoliberalism or even NPM.

The general objective of this article is to study in a critical perspective the NPM, which is one of the main political trends associated to neoliberal ideology. In order to do so, we enlisted three specific objectives, being that each one of them is corresponding to a subsequent part of the text. Firstly, to study in a general perspective a definition about governance, in order to show that it has a general and abstract scope, wider than simply one or another trend about public management. Secondly, it is necessary to focus on the rational choice, as it is an important theory about governance - which was the basis to the development of NPM. And in third - and last - place, we observed the neoliberal foundations of NPM, showing some critical aspects it presented in its real practice.

Methodologically, this work was conduced through a hypothetical-deductive method of research, with a qualitative and critical approach. Its research technique is bibliographic-documental, based mainly in political science scholar works.

\section{Governance: general overview}

Generally, governance is the act or the manner of governing. It "is a term used to describe the making of 
public policy and the delivery of public goods in modern states following the rise of the new right, the development of new public management, public sector reform, and globalization". ${ }^{3}$ Thus, governance refers to several new practices and theories of governing, and the dilemmas they provoke. Some of these theories place less emphasis on the state and hierarchies, and more on markets and networks. ${ }^{4}$ But it does not mean that state and hierarchies have lost their importance with those new theories, practices and dilemmas: "[...] theories of governance ty pically open up the black box of the state. [They] undermine reified concepts of the state as a monolithic entity, interest, or actor"..$^{5}$

Governance can describe the relationship between the state and civil society; mainly that the state does not dominate public policy making. Academic and political interest in governance and the state derive from neoliberal reforms of the public sector since the $1980 \mathrm{~s}^{6}$. For example, public governance is related to reforms that led to a shift from hierarchic bureaucracy towards a consideration of markets and networks as having a greater importance in the public sector. ${ }^{7}$ Globalization has also impacted how states

3 SMITH, M. Pluralism. In: HAY, C.; LISTER, M.; MARSH, D. (eds.). The State: Theories and Issues. New York: Palgrave Macmillan, 2006, p. 21-38; p. 31.

4 BEVIR, Mark. Governance as theory, practice, and dilemma In BEVIR, Mark (ed.). The SAGE Handbook of Governance. Los Angeles; London; New Delhi: SAGE Publications, 2011, p. 1-16; p. 1.

5 BEVIR, Mark. Governance as theory, practice, and dilemma In BEVIR, Mark (ed.). The SAGE Handbook of Governance. Los Angeles; London; New Delhi: SAGE Publications, 2011, p. 1-16; p. 1.

6 BEVIR, Mark. Governance. In Encyclopædia Britannica. Encyclopædia Britannica, inc. Available in:https://www.britannica.com/topic/governance. Access in: 13 May 2019.

7 BEVIR, Mark. What is governance? In BEVIR, Mark (ed.). Public governance. Volume 1. London; Thousand Oaks; New Delhi: SAGE Publications, 2007, p. xxi-xliv; p. xxi. 
and international actors address global or regional issues, such as transnational economies and regional agreements like the European Union (EU). Thus, global governance is related to a political cooperation between transnational and international actors and organizations to address complex issues that no one nation can resolve on its own, such as climate change, development, or conflict resolution and security. These dilemmas which require coordination and cooperation from different stakeholders and different policy arenas are called "wicked issues". 8

There are some general characteristics to the theories and practices related to governance since the 1980s. In the first place, it can be said that governance pays attention to complex interactions and processes of patterns of rule, deviating the focus from state institutions to several other activities, organizations and entities - and this deviation blur the boundary between state and its environment, in a very unconventional manner. In other words, hybrid administrative arrangements are conceived in those new theories: the combination of administrative systems, markets, and non-profit organizations are typically approached, as well as new mixes of public and private (and very often, purely private) in regulation are developed..$^{9}$

A second distinctive trace of new theories of governance is its multi jurisdictional and transnational character, according to which the current patterns of governance

8 Wicked issues defined as "complex, contested problems of interest to multiple policy actors and which require addressing them from different policy domains" (HAWKINS, B.;ALVAREZ-ROSETE, A. Role of the State in Public Health Policy. In QUAH, Stella R. (ed.). International Encyclopedia of Public Health. Amsterdam; London: Academic Press, 2017, p. 407).

9 BEVIR, Mark. Governance as theory, practice, and dilemma In BEVIR, Mark (ed.). The SAGE Handbook of Governance. Los Angeles; London; New Delhi: SAGE Publications, 2011, p. 1-16; p. 2. 
combine institutions and people of diverse levels and sectors of government (international, national, regional, and local).

A third distinctive feature of governance theories is the plurality of stakeholders - which can be described as decurrent of i) increasing use of third-party organizations delivering state services; ii) the explosion of advocacy groups (related to several causes interesting to civil society); iii) the expansion and new prominence of philanthropy. All those causes led to the emergence of new institutional designs and practices, such as collaborative governance and publicprivate partnerships. ${ }^{10}$

New theories about governance stipulate problems for a representative democracy - which is strongly attached to developmental narratives of the nineteenth century, such as liberty, individualism, and the state as safeguards to contain contingency and contestation. But that developmental historicism started its collapse in the beginning of the twentieth century (before the World Wars), when political scientists began to focus on political and voting behavior. After World War I, political scientists, interest groups, and bureaucracies suffered an increasing interest by scientists, as well as a pluralist analysis of the state, the considerations of class struggle by socialists - parameters that debunked the belief in a uniform conception of the nation, state, and common good (and all these new focuses represented a shift from the parameters of the previous century). Moreover, when Rational Choice Theory began its rise between scholars, its microlevel foundations also continued exposing the absurdity of beliefs in the uniformity between institutions (such as nations and states), implying that individuals act

10 BEVIR, Mark. Governance as theory, practice, and dilemma In BEVIR, Mark (ed.). The SAGE Handbook of Governance. Los Angeles; London; New Delhi: SAGE Publications, 2011, p. 1-16; p. 2. 
according to self-interest - even when occupying positions in the state and administration -, also debunking the myth in a common good as a main guide for action in state's agenda. ${ }^{11}$

There are two sides of the new governance: theoretically, it has been something like a stimulus of theories that emphasized less on formal authority and institutions; and in practice, some of its aspects have resulted from those new theories, being that the new theories have been used as attempts to reform the state - sometimes, making it seem like a result of a natural development of things. But new governance is not a natural development: it is "a result of sustained theoretical (or even ideological) advocacy by intellectuals and policy makers" ${ }^{12}$

By now, we can identify that governance is a theoretical concept that overcomes (without putting aside) formal government - and new theories about governance reflect constantly that characteristic. They overflow the traditional scope of the State and its structures, but it does not mean they do not considerate the importance of State institutions, structures and hierarchies: they only take into account a much wider scope of institutions and structures, in which the State is inserted. That wider scope is compound by both public and private actors; national and transnational, also; finally, local and global.

The next section discusses the economic theory that formed the basis of the neoliberal ideology of governance and public management, rational choice theory. Then, the governance debate of the first wave, and a global

11 BEVIR, Mark. New Theories In BEVIR, Mark. Democratic Governance. Princeton; Oxford: Princeton University Press, 2010, p. 39-65; p. 39-40.

12 BEVIR, Mark. Theories of Governance In BEVIR, Mark (ed.). Public governance. Volume 1. London; Thousand Oaks; New Delhi: SAGE Publications, 2007, p. xlv-lxii; p. xlv. 
phenomenon called New Public Management (NPM). This governance trend focused on economic principles mentioned above, such as the "rational self-interested" model and costbenefits analysis. It is this reform of government that was based on a neoliberal ideology.

\section{Rational Choice Theory}

Rational choice is simultaneously a method and a theory about how societal or governing processes work. ${ }^{13}$ This generates questions about the social world, providing some standard techniques up to answer those questions. Its methods mainly include formal modeling techniques originated from social choice theory and games theory. Theoretically, it is based on an economic model of a "selfinterested wealth-maximizing" individual.

In political science, rational choice combine those techniques with economics, from which its intellectual heritage comes, assuming that individuals are able to order their preferences over states, based on their interests. ${ }^{14}$ In

13 DOWDING, Keith. Rational choice theory In BEVIR, Mark (ed.). The SAGE Handbook of Governance. Los Angeles; London; New Delhi: SAGE Publications, 2011, p. 36-50; p. 36-37.

14 It assumes that individuals can order their preferences over states of the world (or 'objects') with the base relation ' $R$ '. We define an ' $R$ ' relation as one where the agent either prefers the first alternative to the other or is indifferent between them, and it can be read as 'at least as good as'. Rational choice theory is defined by three conditions concerned with preferences which are required for rationalizing or interpreting the behavior of agents. Preferences must be reflexive, complete and transitive. The first condition means for any alternative $x$ within a domain A an individual $I$ either prefers or is indifferent between $x$ and itself (for all $x \in \mathrm{A}, x \mathrm{R}_{\mathrm{i}} x$ ). The second condition, completeness, is that any item in domain A must enter into the preference ordering so that for all alternatives $x, y \in \mathrm{A}$, either $x \mathrm{R}_{\mathrm{i}} x$ y or $y x \mathrm{R}_{\mathrm{i}} x$ (or both) (in other words either individual $I$ prefers $y$ to $x$ or is indifferent between them). The final condition means for any triple of alternatives $x, y, z \in A$, if $\mathrm{x}$ $\mathrm{R}_{\mathrm{i}} y$ and $y \mathrm{R}_{\mathrm{i}} x$ and $y \mathrm{R}_{\mathrm{i}} z$, then $x \mathrm{R}_{\mathrm{i}} z$ (which means that if $i$ weakly prefers $x$ to 
other words, this method attempts to explain a social behavior done by the individual, the rational actor or agent. It unpacks patterns of rule, institutions and social facts in general, according to analyses of individuals in activity, modeling individual actions assuming that they adopt the course of action according to their rational preferences..$^{15}$ The greater development of rational choice theory happened during the 1960s and 1970s, as concerns about the expansion of the state, stagflation, budget deficits, and several peripheral analyses of modern "ungovernability" of the state and of inefficien cies caused by political-business cycle ${ }^{16}$ were also growing. ${ }^{17}$

Microlevel emphasis on individual rationality turns the efficiency of the markets into the broadly accepted main coordinator/allocator of resources - but it is very important to highlight that such markets can only operate in a context qualified by suitable laws and norms (including rules that enforce contracts). Thus, many rational choice theorists conceive the problem of governance by explaining the emergence of those suitable laws and norms. But the predominance of the micro level analysis makes it harder to take origins, persistence and effects of norms/laws for

$y$ and to $z$, then I must weakly prefer $x$ to $z$ ). These conditions allow for the weak axiom of revealed preference (WARP) which enables rationalization, interpretation and explanation of behavior (DOWDING, Keith. Rational choice theory In BEVIR, Mark (ed.). The SAGE Handbook of Governance. Los Angeles; London; New Delhi: SAGE Publications, 2011, p. 36-50; p. 36).

15 BEVIR, Mark. New Theories In BEVIR, Mark. Democratic Governance. Princeton; Oxford: Princeton University Press, 2010, p. 39-65; p. 40.

16 This is defined as a period before a re-election, where the incumbent implements economic policies to increase the likelihood of being re-elected. Sometimes, these policies aren't just economic like tax cuts, they could also be capital projects to spur the economy, like building a new road or school.

17 DOWDING, Keith. Rational choice theory In BEVIR, Mark (ed.). The SAGE Handbook of Governance. Los Angeles; London; New Delhi:SAGE Publications, 2011, p. 36-50; p. 38. 
granted. That theory does not explain the rise and stability of law and order when there is no higher authority present, and consequently, rational actors can break the laws if it is in their interests to do so. So, rational choice theorists conclude that such absence means that institutions must be self-enforcing. ${ }^{18}$

\subsection{Rational Choice Institutionalism}

Rational choice institutionalism employs some important logical elements belonging to rational choice theory itself - such as individual rationality and utility. The basic assumption of that kind of institutionalism is that individuals act, in relation to the institutions they occupy (or communicate with) maximizing their own personal interests (which are, in this sense, exogenous). Then, with all those strong exogenous interests brought by individuals, designers of institutions could achieve institutional intentions simply by creating adequate combinations of incentives and disincentives. ${ }^{19}$

Rational choice institutionalism focus its attention mainly on the effects of laws, norms and institutions on the actions of the individuals. Theorists argue that the strategic actions of people are structured by institutions. This theory came about after studying legislators in U.S Congress in the $1970 s^{20}$ meaning that if each actor were behaving in his/

18 BEVIR, Mark. New Theories In BEVIR, Mark. Democratic Governance. Princeton; Oxford: Princeton University Press, 2010, p. 39-65; p. 41.

19 PETERS, B. Guy. Institutional theory In BEVIR, Mark (ed.). The SAGE Handbook of Governance. Los Angeles; London; New Delhi:SAGE Publications, 2011, p. 78-90; p. 80.

20 Hall, P. A. and Taylor, R. C. R. (1996) ‘Political Science and the Three New Institutionalisms', in. Max-Planck-Institut fur Gesellschaftsforschung, Kohn, Germany, pp. 1-32. Available at: http://www.mpifg.de/pu/mpifg_dp/dp966.pdf (Accessed: 20 March 2016). 
her own interest, then many bills would not find a majority. They found an answer in institutions, because of the way procedures and committees are structured in Congress - and this provides and structures the choices and information presented to the legislators. This lowers the transaction $\operatorname{costs}^{21}$ for legislators so they can engage in deal-making. ${ }^{22}$ Thus, stable institutions can give the individuals reasonable expectations about outcomes of several manners of acting, from which they have to choose. In this sense, the ways institutions create expectations about adequate consequences are examined by rational choice institutionalists. ${ }^{23}$ They often think that the global forces (which erode state capacities) are inexorably resultant of a social logic of specialization, according to which, "as society becomes more complex, reciprocal independence becomes the most common relationship among actors". ${ }^{24}$ However, weak institutions (or nations with weak institutions) face high transaction costs, as these cannot give individuals reasonable certainty regarding expectations and consequences. This would create an unstable environment where actors can break the rules without penalty. An example of this would be the international system, ${ }^{25}$ where global governance has no

21 A transaction cost is an economic tern for any costs that occurs during a social interaction or economic exchange. According to North, these can be measurement, enforcement, ideological attitudes and perceptions, and the size of the market. So, for example, there is a transaction cost in enforcing a contract (legal costs). North, D. C. (1990) Institutions, Institutional Change and Economic Performance. Cambridge, UK: Cambridge University Press.

22 Ibid. Hall and Taylor.

23 BEVIR, Mark. New Theories In BEVIR, Mark. Democratic Governance. Princeton; Oxford: Princeton University Press, 2010, p. 39-65; p. 47.

24 BEVIR, Mark. New Theories In BEVIR, Mark. Democratic Governance. Princeton; Oxford: Princeton University Press, 2010, p. 39-65; p. 49.

25 BEVIR, Mark. New Theories In BEVIR, Mark. Democratic Governance. Princeton; Oxford: Princeton University Press, 2010, p. 39-65; p. 41-42 
hierarchy and enforcement mechanisms are weak.

Even though rational choice theory is an organizing perspective and a way of analyzing politics, it makes no specific recommendations about governance structures. It also does not have theories about governance or new modes of service delivery. However, it is used to model problems that arise in new forms of governance, helping providing normative critique (or justification) for them. ${ }^{26}$ Much of political science and governance studies have been dominated by rational choice-based models and analyses for the last four decades, and these are some of its impacts below.

An important first impact that can be enlisted here is about the contingency of human behavior. The main contribution rational choice theory provides is that behavior is organized around maximizing wealth or preferences of the individual, and thus, there is an assumption that these preferences are static and all behaviors are strategic and highly calculated to achieve these ends. ${ }^{27}$ However, there are many example in politics, especially in voting, that demonstrate not all decisions are highly strategic or even well-informed, as in the case of the U.K.'s 2016 referendum on Brexit. ${ }^{28}$ But giving information to voters does affect selection of candidates. ${ }^{29}$ In addition, given the highly

26 DOWDING, Keith. Rational choice theory In BEVIR, Mark (ed.). The SAGE Handbook of Governance. Los Angeles; London; New Delhi:SAGE Publications, 2011, p. 36-50; p. 36-37.

27 HALL, P. A.; TAYLOR, R. C. R. Political Science and the Three New Institutionalisms. Köln: Max-Planck-Institut fur Gesellschaftsforschung, 1996, p. 1-32. Available at: http://www.mpifg.de/pu/mpifg_dp/dp96-6.pdf. Access in: 13 May 2019.

28 ENGLISH, O. The British public still have no idea what they voted for with Brexit - it's not elitist to admit it. The Independent, 22 January 2019. Available at: https://www.independent.co.uk/voices/brexit-theresa-may-leave-votersremain-eu-referendum-campaign-deal-a8740526.html. Access in: 13 May 2019.

29 PANDE, R. Can informed voters enforce better governance? Experiments in 
complex nature of human beings, it is a flaw to assume that these preferences are the same, or to be able to assume what the preferences of these individuals are, given cultural or religious barriers.

The second impact we highlight is about high inefficiency in allocating some goods (which can be understood through the free riding problem). In the social sciences, the free rider problem occurs when one or more persons benefit from common or public goods without having to pay for them. Public goods or common goods are economic terms to define resources that are not excludable, such as clean air or grass for a farmer to let his cattle graze. ${ }^{30}$ Clean air is a public good because it is non excludable and non rivalrous, meaning anyone can benefit from breathing clean air, and many people can breathe the same air (non rivalrous). However, grass is rivalrous as two cows cannot eat the same pile of grass or fisheries, as two persons cannot catch the same fish. So, these are called common or communal goods; non excludable but rivalrous.

Free riding presents an economic inefficiency, if an actor feels that someone else is benefiting without incurring a cost, then she or he may not want to contribute as much. This can lead to the underproduction of these goods and overconsumption of the goods too. Rational choice and subsequent models, such as public choice theory, predict these collective action problems. However, there is rarely a solution within these models to solve them, since the actor will behave in his or her preferences.

low-income democracies. Annual Review of Economics, v. 3, n. 1, p. 215-237, 2011.

30 BROUSSEAU, E.; DEDEURWAERDERE, T. Global Public Goods: The Participatory Governance Challenges in: BROUSSEAU, E.; DEDEURWAERDERE, T.; SIEBENHÜNER, (eds.). Reflexive Governance for Global Public Goods. London: MIT Press, 2012, p. 21-36. 
The third contribution brought by rational choice theory is about long-term cooperation. Assuming that people act rationally according to their own interests even when occupying positions within the state, rational choice theorists have to explain how political and social order can be stable, given that people could break such orders if it is in their interests to do so. An explanation often given is that an authority creates incentives and disincentives, so people include sustaining such order within their interests too ${ }^{31}$ however, that explanation does not answer the question of how orders are maintained stable when a higher authority is absent, which leads to this question: how can a higher authority arise in the first place ${ }^{32}$

Generally those theorists conclude that the only way of preventing the tragedy of the commons ${ }^{33}$ is the establishment of a system of coercion that is mutually accepted - as coercion acts as a corrective feedback mechanism that ensures honesty in the population. Even when coercion restricts freedom (or even when it is not equitable/just), it would be the only alternative to social instability (or even ruin). ${ }^{34}$

Since the rational choice model only explains behavior in a competitive environment for private goods, is not a

31 BEVIR, Mark. Theories of Governance In BEVIR, Mark (ed.). Public governance. Volume 1. London; Thousand Oaks; New Delhi: SAGE Publications, 2007, p. xlv-xlvii.

32 BEVIR, Mark. New Theories In BEVIR, Mark. Democratic Governance. Princeton; Oxford: Princeton University Press, 2010, p. 39-65; p. 42.

33 Tragedy of the Commons is a metaphoric concept to describe a situation of a shared resource, where every individual acts to his or her own selfinterest, but this has a long-term negative impact on the common good, usually the depletion of the shared resource. This is usually cited in works with sustainable development or environmental or conservation efforts (OSTRÖM, E. Governing the Commons: The Evolution of Institutions for Collective Action. New York: Cambridge University Press, 1990).

34 BEVIR, Mark. New Theories In BEVIR, Mark. Democratic Governance. Princeton; Oxford: Princeton University Press, 2010, p. 39-65; p. 43. 
broad theory to explain every behavior or decision of all individuals ${ }^{35}$. For example, in a situation where there are limited natural resources in a community, such as fisheries, each individual acting to maximize his or her self-interests would lead to overexploitation. In the short-term this may provide some gratification, but could be devastating in the long-term if these natural resources were depleted. Thus, would it be rational for an individual to maximize his or her opportunities for short-term gratification? Or cooperate with community members to share the resources judiciously, so that they will not deplete?

In another example, regarding election cycle, the rational choice model may actually be undemocratic. The short electoral cycles can encourage the rational choice of "short-term gratification" as politicians will only be concerned with surviving the next campaign cycle and not the policies that extend beyond them. ${ }^{36}$ Thus, laws and policies put in place by politicians may not benefit the communities in the long-term but are only meant to boost a candidate's popularity for the next campaign cycle. A common example is pork barreling in American politics. This is the appropriation of funds to a legislator's district, solely to receive his or her vote on a bill. The funding may have absolutely nothing to do with the contents of the bill, but is simply to win his or her vote. ${ }^{37}$ This is where some scholars, who argue that this is a "big welfare state" and say that this is "inefficiency" may lead to a type of state failure.

35 OSTRÖM, E. Beyond Markets and States: Polycentric Governance of Complex Economic Systems. American Economic Review, v. 100, n. 3, p. 641-672, 2010.

36 BALDWIN, K. The Paradox of Traditional Chiefs in Democratic Africa. New York: Cambridge University Press, 2015.

37 BICKERS, Kenneth N.; STEIN, Robert M. The Congressional Pork Barrel in a Republican Era. The Journal of Politics, v. 62, n. 4, p. 1070-1086, 2008. 
Rational choice theory (through two of its major branches, public choice and constitutional political economy) provide some superficial justification for new governance techniques of networks and markets. Both public choice and constitutional political economy defend markets and celebrate the complexity and diversity of such new institutional arrangements.

However, rational choice analysis has revealed the instability (and the chaos) resulting of political formation without institutional structures that narrow broad sets of possibilities. It has specified strategic possibilities that groups and individuals may use when their understanding of aggregation mechanisms is better than others'. It also warns about the dangers of regulation when agencies capture regulators because of their own interests, and inequities and inefficiencies resulting from the diversity of groups' mobilization problems. Those (between several other ones) make rational choice approach a way to criticize new governance systems. ${ }^{38}$

Public choice theory assumes that rational behavior is based on one's knowledge of the situation. ${ }^{39}$ Individual preferences and free choice are central to this theory, and the social reality is assessed by the individual's action, logic of the situation, and logic of the action. In other words, a "Native-American who believes that rain-dancing produces rain and who begins to dance in a severe drought is behaving rationally." ${ }^{40}$ This is theory, which is based on rational actor

38 DOWDING, Keith. Rational choice theory In BEVIR, Mark (ed.). The SAGE Handbook of Governance. Los Angeles; London; New Delhi:SAGE Publications, 2011, p. 36-50; p. 46.

39 GRUENING, G. Origin and theoretical basis of New Public Management. International Public Management Journal, v. 4, p. 1-25, 2001.

40 GRUENING, G. Origin and theoretical basis of New Public Management. International Public Management Journal, v. 4, p. 1-25, 2001, p. 5. 
model, is also one of the leading theories for a popular governance model called New Public Management.

\section{Neoliberalism, New Public Management (NPM) and Governance}

The ideological usage of new governance has been expressed as a political culture of the minimal state and less government. In practice, however, social scientists often concluded that the neoliberal reforms of the public sector seldom reverted the role of state institutions, but rather destroyed social safety nets, such as healthcare and education and in the United States (U.S) in particular, placed the tax burden on the working majority rather than the wealthy elite..$^{41}$ The result is an empty rhetoric of "less government" in governance, and the consequences of the reforms can be expressed as fragmented service delivery and weakened central control without the establishment of proper markets. ${ }^{42}$

NPM is a concept that has many theoretical roots and can be traced as far back as the post-World War II era in the U.S. ${ }^{43}$ The theories (public choice and principal-agent) ${ }^{44}$ imply

41 NAVARRO, V. Neoliberalism as a Class Ideology: Or, The Political Causes of the Growth of Inequalities in: NAVARRO, V. (ed.). Neoliberalism, Globalization, and Inequalities: Consequences for Health and Quality of Life. Amityville: Baywood Publishing Company, 2007, p. 9-23.

42 BEVIR, Mark. What is governance? In BEVIR, Mark (ed.). Public governance. Volume 1. London; Thousand Oaks; New Delhi: SAGE Publications, 2007, p. xxi-xliv; p.xxiv.

43 HOOD, C. A Public Management for All Seasons? Public Administration, v. 69, n. 1, p. 3-19, 1991.

44 In principal-agent theory, we have the Principal (or multiple Principals) that may have certain interests: like share-holders of a pharmaceutical company, donors to a charity or fund, or member states of the EU. The Agent is tasked with executing services or acts for the Principal(s); however, according to Grossman \& Hart (1983) an agency problem can develop if the Agent has an agenda that differs from the Principal(s) and decides to pursue his/her own 
transferring to political theory and public administration, the methods and principles of neoclassical economics. These principles rely on radical logical-deductive and abstract, rather than historical-deductive character; and the economic agents are, rightly so, about maximizing the markets (and not public interests/goods). In the case of political behavior, the maximization of self-interest is universally accepted..$^{45}$

The popularity of NPM rose after the 1973-1974 oil shocks and the subsequent recession in the early 1980s; the "welfare state and its intrusive policies" were blamed for the crisis ${ }^{46}$. The rise in new-right administrations in the U.S (President Regan) and the United Kingdom (U.K) (Prime Minister Thatcher) led the movement for government reforms. According to Miller \& Dunn (2006), the original principles of NPM are not defined from a single theory but seen "as practical solutions to operational problems

\section{interests instead.}

For example, in a perfect two-party democratic system, if voters (Principals) had full knowledge of the politician's (Agent) platform and intentions then they would choose based on those that closely align to the political values and legislation of their own preference (Lane 2013). Thus, this implies that extreme right-wing or left-wing candidates would not have been elected in a fair election had voters had all the information regarding the political agent (GROSSMAN, S.; HART, O. An Analysis of the Principal-Agent Problem. Econometrica, v. 51, n. 1, p. 7-45, 1983;

LANE, J.-E. The Principal-Agent Approach to Politics: Policy Implementation and Public Policy-Making. Open Journal of Political Science, v. 3, n. 2, p. 85-89, 2013).

45 BRESSER-PEREIRA, L. C. Theoretical Approaches to New Public Management. In BRESSER-PEREIRA, L. C. (ed.). Democracy and Public Management Reform: Building the Republican State. Oxford: Oxford University Press, 2004.

46 LARBI, G. A. (1999). The New Public Management Approach and Crisis States. Geneva: United Nations Research Institute for Social Development, 1999. Available at: http://www.unrisd.org/80256B3C005BCCF9/(httpAuxP ages)/5F280B19C6125F4380256B6600448FDB/\$file/dp112.pdf. Access in: 13 May 2019. 
confronting governments" ${ }^{\prime 4}$. These principles were generated as remedies to a "broken system of government" where state institutions were viewed as undemocratic, unresponsive, inefficient and failing in other categories that are used to measure an efficient organization. Specifically, the reforms attempted to make governments function more "efficiently" and even "entrepreneurially," like a business ${ }^{48}$. This was an attempt to reinvent the state and distinguish "steering" (policy decisions) which is what a modern state needed more of, rather than "rowing" (service delivery), which it needed less of.

\subsection{Neoliberal Foundations}

NPM became popular as an academic and then policy discourse, however the ideology behind it to justify government reforms was neoliberalism. ${ }^{49}$ For example, an argument of the "big and intrusive" government was called "state failure". Hindmoor describes this as a parallel concept of market failure, where markets are imperfect and

47 MILLER D. Y.; DUNN, W. N. A Critical Theory of New Public Management, 2006. Available at: http://citeseerx.ist.psu.edu/viewdoc/download?doi=10.1 .1.125.4697\&rep=rep1\&type=pdf. Accessed in: 13 May 2019, p. 3.

48 VAN KERSBERGEN, K.; VAN WAARDEN, F. (2004). “Governance” as a bridge between disciplines: Cross-disciplinary inspiration regarding shifts in governance and problems of governability, accountability and legitimacy. European Journal of Political Research, v. 43, n. 2, p. 143-171, 2004.

49 BESSANT, S. E. F.; ROBINSON, Z. P.; ORMEROD, R. M. Neoliberalism, new public management and the sustainable development agenda of higher education: history, contradictions and synergies. Environmental Education Research, v. 21, n. 3, p. 417-432, 2015.¿CONNELL, R.; FAWCETT, B.; MEAGHER, G. Neoliberalism, New Public Management and the human service professions: Introduction to the Special Issue. Journal of Sociology, v. 45, n. 4, p. 331-338, 2009; URIO, P. China, the West and the Myth of New Public Management: Neoliberalism and its Discontents. New York, NY: Routledge, 2012. 
sometimes the state needs to intrude (bring in regulations). However, scholars argue that the state is imperfect and thus some services (like education or health) should be privatized so citizens can have a greater say or another choice in the market. ${ }^{50}$ Some forms of state failure include rent-seeking, political business cycles, vote swapping, and budget-maximizing.

NPM is broadly shaped by free market or liberal economic principles, such as competition. Thus, once services are delivered through privatization, there will be greater and (ideally) better options for consumers (citizens). So, in some areas, governments try to stimulate competition (a bid for contracts, for example), rather than replicate markets. ${ }^{51}$ However, governments may not always get a perfect outcome on demand and supply, when trying to stimulate competition and therefore may be inefficient ${ }^{52}$ by raising transaction costs.

Steering is a less invasive government, where services are no longer delivered by the government, but policies were created to "guide" local governments and private actors..$^{53}$ As a result, many industries were privatized or outsourced to contractors as well as quasi-markets of joint public-private

50 HINDMOOR, A. Public Choice in: HAY, C.; LISTER, M.; MARSH, D. (eds.) The State: Theories and Issues. New York: Palgrave Macmillan (Political Analysis), 2006, p. 79-97.

51 O'FLYNN, J. From New Public Management to Public Value: Paradigmatic Change and Managerial Implications. The Australian Journal of Public Administration, v. 66, n. 3, p. 353-366, 2007.

52 O'FLYNN, J. From New Public Management to Public Value: Paradigmatic Change and Managerial Implications. The Australian Journal of Public Administration, v. 66, n. 3, p. 353-366, 2007.

53 VAN KERSBERGEN, K.; VAN WAARDEN, F. (2004). "Governance" as a bridge between disciplines: Cross-disciplinary inspiration regarding shifts in governance and problems of governability, accountability and legitimacy. European Journal of Political Research, v. 43, n. 2, p. 143-171, 2004. 
partnerships initiatives (JPPPIs) were formed.$^{54}$ However, these moves did not lower costs, but may have increased them; agents can "shirk ${ }^{55}$ under long-term contracting arrangements, so alternatives ways for agents to engage in opportunism exist under short- term contracting, all allowing for agents to pretend they are better than they really are".$^{56}$ Steering, rather than providing services directly ("rowing") can also have problems with accountability, transparency, and even a political cost. In terms of accountability, with a stakeholder net casted so widely, it may be difficult for the public to know who is accountable especially when services and goods are delivered poorly. ${ }^{57}$ Thus, NPM may address operational or administrative accountability measures (with incentives and deterrents) however, not political accountability. ${ }^{58}$

Originally, many of these ideals came from the business sector and therefore had a "universal appeal" to be

54 GREENWOOD, D. Governance, Coordination, and Evaluation The Case for an Epistemological Focus and a Return to C. E. Lindblom. Political Research Quarterly, v. 69, n. 1, p. 30-42, 2016.

55 Shirk or shirking means when an Agent intentionally avoid executing delegated duties or functions that it was contracted to do on behalf of the Principal(s) (KAMRADT-SCOTT, A. Managing Global Health Security: The World Health Organization and Disease Outbreak Control. London: Palgrave MacMillan, 2015).

56 LANE, J.-E. The Principal-Agent Approach to Politics: Policy Implementation and Public Policy-Making. Open Journal of Political Science, v. 3, n. 2, p. 85-89, 2013, p. 88.

57 BLUESTONE, K.; HEATON, A.; LEWIS, C. Beyond Philanthropy: the pharmaceutical industry, corporate social responsibility, and the developing world. London: VSO; Save the Children; and Oxfam, 2002. Available at: http://www.savethechildren.org.uk/sites/default/files/docs/Beyond_ Philanthropy_1.pdf. Accessed in: 13 May 2019.

58 FATEMI, M.; BEHMANESH, M. R. New Public Management Approach and Accountability. International Journal of Management, Economics, and Social Sciences, v. 1, n. 2, p. 42-49, 2012. 
incorporated in any government or public administration. ${ }^{59}$ However, there are contextual differences in how the public and private sector operate. The business sector is based on a model of for-profits and not public goods, so some concepts, such as collaboration or public interest do not exist in this framework. NPM is limited in terms of transferring privatesector strategies into the public sector. ${ }^{60}$

Advocators for NPM support a democratic and pluralist style of governance, but in practice, conflict can evolve when actors have divergent interests. NPM's theoretical underpinnings, based on economic costs and self-interest, do not have a sufficient way on how to resolve these conflicts in the public sector. Additionally, although these policies have helped to depoliticize some issues (such as health or education), they did not actually negate the fact that resources are politically determined. An agent's incentive can be motivated by politics or self-interests but obscured through a loosely networked bureaucracy. In other words, NPM not only failed to make the public sector more efficient, but also failed to address other problems, like corruption and transparency.

As a state failure, rent-seeking or budget maximization are ways that the state or actors within the state, are able to increase power and wealth while producing little social efficiency. ${ }^{61}$ Retrenching the state, via NPM reforms, and leaving more services to the free market were supposed to correct these failures. However, some governments or

59 HOOD, C. A Public Management for All Seasons? Public Administration, v. 69, n. 1, p. 3-19, 1991.

60 MONGKOL, K. The Critical Review of New Public Management Model and its Criticisms. Research Journal of Business Management, v. 5, n. 1, p. 35-43, 2011.

61 HINDMOOR, A. Public Choice in: HAY, C.; LISTER, M.; MARSH, D. (eds.) The State: Theories and Issues. New York: Palgrave Macmillan (Political Analysis), 2006, p. 79-97. 
heads of state are worried about being seen as corrupt and make efforts to appear anti-corrupt, but individuals who are offered thousands of dollars by private companies do not share that same concern. A deregulated market means that states no longer have oversight, investigatory, or auditing of institutions and companies.

In addition, cost-effectiveness and outputs are emphasized rather than inputs (collecting bribes) or the process (receiving kickbacks from contractors) or social impact (pollution). This means that success or failure is determined by time and money (outputs), and not by the other factors. If services are delivered in a way that is not cost-efficient (for consumers and producers), it could be seen as a failing program, even if the services provided are in the public's interest. Or if it is delivered in a cost-effective way, it could be viewed as successful even if it was not in the public's interest $^{62}$. This type of evaluation leaves out some important issues to consider, such as corruption or democratization.

\subsection{Building the State with Neoliberalism}

There are some critiques about how NPM is a Westernstyle movement that makes some assumptions about the institutions and culture that may be present in the U.S, Australia, or the U.K, but not necessarily in Africa, Latin America or Asia. NPM-style reforms were imposed in many low-income countries by donor institutions such as the World Bank and International Monetary Fund to adjust the state for "good governance." ${ }^{63}$ Sub-Saharan Africa (SSA)

62 HOOD, C. A Public Management for All Seasons? Public Administration, v. 69, n. 1, p. 3-19, 1991.

63 LARBI, G. A. The New Public Management Approach and Crisis States. Geneva: United Nations Research Institute for Social Development, 1999. Available 
was more impacted than other regions of the world for length and depth of reforms it adopted. ${ }^{64}$ However, NPM had not fixed the problems with inefficiency and corruption that donors thought it would; first there was an assumption that there is an efficient market and private sector. Second, the strong patronage system present in some countries undermined benefits to be derived from contracting out, instead, it simply moved corruption to the private sector. ${ }^{65}$ And since NPM is market-oriented, public services are using "market niche seeking" behavior where they are gearing their services towards those with the ability to pay and not where the greatest needs are. The disparity of services, such as health, education, and sanitation, affects poor countries the most; ${ }^{66}$ power and wealth is highly concentrated in the urban capitals, which leaves the vast rural poor with few options. In some cases, good services and facilities that were conduced by specialized technicians (such as sanitation) had that personnel substituted by professional managers and for-profit practices and values. ${ }^{67}$

at: http://www.unrisd.org/80256B3C005BCCF9/(httpAuxPages)/5F280B19 C6125F4380256B6600448FDB/\$file/dp112.pdf. Access in: 13 May 2019, p. 65.

64 GODDARD, Andrew; MKASIWA, Tausi Ally. New public management and budgeting practices in Tanzanian Central Government: "Struggling for conformance". Journal of Accounting in Emerging Economies, v. 6, n. 4, p.340371, 2016. Available at: https://doi.org/10.1108/JAEE-03-2014-0018. Accessed in: 13 May 2019.

65 LARBI, G. A. The New Public Management Approach and Crisis States. Geneva: United Nations Research Institute for Social Development, 1999. Available at: http://www.unrisd.org/80256B3C005BCCF9/(httpAuxPages)/5F280B19 C6125F4380256B6600448FDB/\$file/dp112.pdf. Access in: 13 May 2019.

66 SCAFF, Elisangela Alves da Silva; SOUZA, Kellcia Rezende; PAXE, Isaac. Implications of the New Public Management in Education: Comparative Analysis between Brazil and Angola. Education Policy Analysis Archives, v. 26, n. 129, October 15, p. 1-31, 2018.

67 VAN ROOYEN, Carina. New public management as a mechanism of accumulation by dispossession: The case of a public bulk water provider in South Africa in: HALVORSEN, Tor; IBSEN, Hilde; EVANS, Henri-Count; 
Finally, proponents of NPM claim that a free marketbased services would bring more democratic participation as citizens would have greater control and say, over services. However, an argument has been proposed that the marketization of services, such as health or education, have been undemocratic; especially to poor and vulnerable citizens as providers allocate goods and services to those who are most able to pay and as explain above, that tends to be in urban areas in low income countries. ${ }^{68}$ Although many countries that have adopted NPM-style reforms still perform democratic rituals, such as holding elections, with the rising influence of the private and third sector (nonprofit) in policy making, "there are often few lines of accountability tying these actors back to elected officials, and those few are too long to be effective," ${ }^{\prime 9}$. In addition, even with the second wave of governance reforms (network governance or collaborative governance) there is no agreement on how to promote democracy. ${ }^{70}$

PENDERIS Sharon (eds.). Knowledge for justice: Critical perspectives from southern African-Nordic research partnerships. Cape Town; Bellville: African Minds; The Southern African-Nordic Centre, 2017, p. 71-92.

BEVIR, Mark. Governance. In Encyclopædia Britannica. Encyclopædia Britannica, inc. Available in:https://www.britannica.com/topic/ governance. Access in: 13 May 2019; LARBI, G. A. The New Public Management Approach and Crisis States. Geneva: United Nations Research Institute for Social Development, 1999. Available at: http://www.unrisd. org/80256B3C005BCCF9/(httpAuxPages)/5F280B19C6125F4380256B660044 8FDB/\$file/dp112.pdf. Access in: 13 May 2019, p. 65; O’FLYNN, J. From New Public Management to Public Value: Paradigmatic Change and Managerial Implications. The Australian Journal of Public Administration, v. 66, n. 3, p. 353-366, 2007.

69 BEVIR, Mark. Governance. In Encyclopædia Britannica. Encyclopædia Britannica, inc. Available in:https://www.britannica.com/topic/governance. Access in: 13 May 2019.

70 BEVIR, Mark. Governance. In Encyclopædia Britannica. Encyclopædia Britannica, inc. Available in:https://www.britannica.com/topic/governance. 


\section{Conclusion}

After all the argumentation above, it is time to write some final considerations and conclusions about the researched subject. In first place, we have to conclude that governance is a much wider concept than government itself. It is an idea about relationships between the state and nonstate institutions, actors and networks, but without putting aside the importance of the state. Private and public, national and transnational, global and local actors, institutions and networks are studied by the several theories conceived inside the debate about governance.

One of the most important theories about governance is the rational choice one. It focuses on the microlevel (individual rationality), and through that, we can affirm that the market is emphasized as the main allocator/coordinator of resources - but the theory also depends on a context qualified by adequate laws and norms to work (which, by its side, depends on state activities and power). But that theory does not explain the rise of stability, law and order when there is no higher authority present - thus, individuals can break the laws and norms if the consecution their interests depends on that infractions.

But it neither makes specific recommendations about governance structures; nor have theories about governance structures. It does not have theories about governance, or even new models of service delivery: it is only used to model problems that arise in new forms of governance, providing critique or justification for them - and it is important to highlight important consequences to political sciences brought by rational choice:

Access in: 13 May 2019. 
1. It shows that behaviors are organized around maximizing individual wealth or preferences - but it also can provide an erroneous conclusion, according to which human preferences are static, and that every behavior are highly calculated to achieve these ends (when it is a current consensus shown by psychology and social sciences in general that human behavior is much more contingent and based on emotional, unconscious and cultural factors, as well as much more changeable than modern preconceptions assume).

2. Some economic problems about collective action, such as the free rider one, show an economic inefficiency of allocating resources, are predicted by rational choice theory - and this can lead to underproduction and/or overconsumption of those goods (including health and education services). But rational choice theorists rarely show a solution to those problems, as individual actors will always act according to their individual interests and preferences.

3. Rational choice theorists show that individuals will rationally act according to their own interests, even when occupying positions within the state, and this is a good impact to political theory, as it reveals the "black box of the state". An explanation to this problem is given by the theory on this basis: state law and order must create incentives and disincentives (such as a system of coercion), then people would balance their interests/preferences including sustaining such order. But rational choice theory does not even explain how a higher authority arises, taken it by always present.

Rational choice theory is one of the basis on which a very significant trend of governance, the New Public Management (NPM), was erected - and the ideological usage of that new trend has been expressed in a culture of 
minimal state (and consequently, less government). But in practice, social scientists often concluded that such culture, when embossing implemented reforms, seldom reverted the role of the state, and destroyed social safety nets, as well as placed the tax burden on the working majority rather than on the wealthy elite. Then, such rhetoric is expressible in fragmented service delivery and weakened central control without establishment of adequate (private) markets for offering those social services (such as education and health).

It has also to be affirmed that advocates for NPM have Western-shaped minds - and they generally make erroneous assumptions about institutions and cultures, which may be present in Anglo-American countries, but not in Africa and Asia, for example. It has to be also shown that, in practice, NPM-style reforms were imposed to lowincome countries by donor institutions to adjust their states for good governance - but those reforms did not solve problems with inefficiency and corruption (making it even worse sometimes, as corruption started growing hugely in private sector also in those countries).

Disparity in essential services distribution also happened in those countries - where power and wealth are hugely concentrated in urban capitals. Consequently, vast rural poor populations were left with few options, as private companies offering those services would not install facilities near their places.

Finally, although many poor countries have adopted democratic institutions after the impassion of NPM-style reforms, the promotion of democracy after the continuity of such kind of reforms could not be verified. 


\section{Referências}

BALDWIN, K. The Paradox of Traditional Chiefs in Democratic Africa. New York: Cambridge University Press, 2015.

BESSANT, S. E. F.; ROBINSON, Z. P.; ORMEROD, R. M. Neoliberalism, new public management and the sustainable development agenda of higher education: history, contradictions and synergies. Environmental Education Research, v. 21, n. 3, p. 417-432, 2015.

BEVIR, Mark. Governance. In Encyclopædia Britannica. Encyclopædia Britannica, inc. Available in:https://www. britannica.com/topic/governance. Access in: 13 May 2019. BEVIR, Mark. Governance as theory, practice, and dilemma In BEVIR, Mark (ed.). The SAGE Handbook of Governance. Los Angeles; London; New Delhi: SAGE Publications, 2011, p. $1-16$.

BEVIR, Mark. New Theories In BEVIR, Mark. Democratic Governance. Princeton; Oxford: Princeton University Press, 2010, p. 39-65.

BEVIR, Mark. Theories of Governance In BEVIR, Mark (ed.). Public governance. Volume 1. London; Thousand Oaks; New Delhi: SAGE Publications, 2007, p. xlv-lxii.

BEVIR, Mark. What is governance? In BEVIR, Mark (ed.). Public governance. Volume 1. London; Thousand Oaks; New Delhi: SAGE Publications, 2007, p. xxi-xliv.

BICKERS, Kenneth N.; STEIN, Robert M. The Congressional Pork Barrel in a Republican Era. The Journal of Politics, v. 62, n. 4, p. 1070-1086, 2008.

BLUESTONE, K.; HEATON, A.; LEWIS, C. Beyond Philanthropy: the pharmaceutical industry, corporate social 
responsibility, and the developing world. London: VSO; Save the Children; and Oxfam, 2002. Available at: http:// www.savethechildren.org.uk/sites/default/files/docs/ Beyond_Philanthropy_1.pdf. Accessed in: 13 May 2019.

BRESSER-PEREIRA, L. C. Theoretical Approaches to New Public Management. In BRESSER-PEREIRA, L. C. (ed.). Democracy and Public Management Reform: Building the Republican State. Oxford: Oxford University Press, 2004.

BROUSSEAU, E.; DEDEURWAERDERE, T. Global Public Goods: The Participatory Governance Challenges in: BROUSSEAU, E.; DEDEURWAERDERE, T.; SIEBENHÜNER, (eds.). Reflexive Governance for Global Public Goods. London: MIT Press, 2012, p. 21-36.

CONNELL, R.; FAWCETT, B.; MEAGHER, G. Neoliberalism, New Public Management and the human service professions: Introduction to the Special Issue. Journal of Sociology, v. 45, n. 4, p. 331-338, 2009.

DOWDING, Keith. Rational choice theory In BEVIR, Mark (ed.). The SAGE Handbook of Governance. Los Angeles; London; New Delhi: SAGE Publications, 2011, p. 36-50.

ENGLISH, O. The British public still have no idea what they voted for with Brexit - it's not elitist to admit it. The Independent, 22 January 2019. Available at: https://www. independent.co.uk/voices/brexit-theresa-may-leave-voters-remain-eu-referendum-campaign-deal-a8740526.html. Access in: 13 May 2019.

FATEMI, M.; BEHMANESH, M. R. New Public Management Approach and Accountability. International Journal of Management, Economics, and Social Sciences, v. 1, n. 2, p. 42-49, 2012.

GODDARD, Andrew; MKASIWA, Tausi Ally. New public management and budgeting practices in Tanzanian Central 
Government: "Struggling for conformance". Journal of Accounting in Emerging Economies, v. 6, n. 4, p. 340-371, 2016. Available at: https://doi.org/10.1108/JAEE-03-2014-0018. Accessed in: 13 May 2019.

GREENWOOD, D. Governance, Coordination, and Evaluation The Case for an Epistemological Focus and a Return to C. E. Lindblom. Political Research Quarterly, v. 69, n. 1, p. 30-42, 2016.

GROSSMAN, S.; HART, O. An Analysis of the Principal-Agent Problem. Econometrica, v. 51, n. 1, p. 7-45, 1983.

GRUENING, G. Origin and theoretical basis of New Public Management. International Public Management Journal, v. 4, p. 1-25, 2001.

HALL, P. A.; TAYLOR, R. C. R. Political Science and the Three New Institutionalisms. Köln: Max-Planck-Institut fur Gesellschaftsforschung, 1996, p. 1-32. Available at: http:/ / www.mpifg.de/pu/mpifg_dp/dp96-6.pdf. Access in: 13 May 2019.

HAWKINS, B.;ALVAREZ-ROSETE, A. Role of the State in Public Health Policy. In QUAH, Stella R. (ed.). International Encyclopedia of Public Health. Amsterdam; London: Academic Press, 2017.

HINDMOOR, A. Public Choice in: HAY, C.; LISTER, M.; MARSH, D. (eds.) The State: Theories and Issues. New York: Palgrave Macmillan (Political Analysis), 2006, p. 79-97.

HOOD, C. A Public Management for All Seasons? Public Administration, v. 69, n. 1, p. 3-19, 1991.

KAMRADT-SCOTT, A. Managing Global Health Security: The World Health Organization and Disease Outbreak Control. London: Palgrave MacMillan, 2015. 
LANE, J.-E. The Principal-Agent Approach to Politics: Policy Implementation and Public Policy-Making. Open Journal of Political Science, v. 3, n. 2, p. 85-89, 2013.

LARBI, G. A. The New Public Management Approach and Crisis States. Geneva: United Nations Research Institute for Social Development, 1999. Available at: http://www. unrisd.org/80256B3C005BCCF9/(httpAuxPages)/5F280B 19C6125F4380256B6600448FDB/\$file/dp112.pdf. Access in: 13 May 2019.

MILLER D. Y.; DUNN, W. N. A Critical Theory of New Public Management, 2006. Available at: http:// citeseerx. ist.psu.edu/viewdoc/download?doi=10.1.1.125.4697\&rep =rep1\&type=pdf. Accessed in: 13 May 2019.

MONGKOL, K. The Critical Review of New Public Management Model and its Criticisms. Research Journal of Business Management, v. 5, n. 1, p. 35-43, 2011.

NAVARRO, V. Neoliberalism as a Class Ideology: Or, The Political Causes of the Growth of Inequalities In: NAVARRO, V. (ed.). Neoliberalism, Globalization, and Inequalities: Consequences for Health and Quality of Life. Amityville: Baywood Publishing Company, 2007, p. 9-23.

O'FLYNN, J. From New Public Management to Public Value: Paradigmatic Change and Managerial Implications. The Australian Journal of Public Administration, v. 66, n. 3, p. 353-366, 2007.

OSTRÖM, E. Beyond Markets and States: Polycentric Governance of Complex Economic Systems. American Economic Review, v. 100, n. 3, p. 641-672, 2010.

OSTRÖM, E. Governing the Commons: The Evolution of Institutions for Collective Action. New York: Cambridge University Press, 1990. 
PANDE, R. Can informed voters enforce better governance? Experiments in low-income democracies. Annual Review of Economics, v. 3, n. 1, p.215-237, 2011.

PETERS, B. Guy. Institutional theory In BEVIR, Mark (ed.). The SAGE Handbook of Governance. Los Angeles; London; New Delhi: SAGE Publications, 2011, p. 78-90.

SCAFF, Elisangela Alves da Silva; SOUZA, Kellcia Rezende; PAXE, Isaac. Implications of the New Public Management in Education: Comparative Analysis between Brazil and Angola. Education Policy Analysis Archives, v. 26, n. 129, October 15, p. 1-31, 2018.

SMITH, M. Pluralism. In: HAY, C.; LISTER, M.; MARSH, D. (eds.). The State: Theories and Issues. New York: Palgrave Macmillan, 2006, p. 21-38.

URIO, P. China, the West and the Myth of New Public Management: Neoliberalism and its Discontents. New York, NY: Routledge, 2012.

VAN KERSBERGEN, K.; VAN WAARDEN, F. “Governance" as a bridge between disciplines: Cross-disciplinary inspiration regarding shifts in governance and problems of governability, accountability and legitimacy. European Journal of Political Research, v. 43, n. 2, p. 143-171, 2004.

VAN ROOYEN, Carina. New public management as a mechanism of accumulation by dispossession: The case of a public bulk water provider in South Africa in: HALVORSEN, Tor; IBSEN, Hilde; EVANS, Henri-Count; PENDERIS Sharon (eds.). Knowledge for justice: Critical perspectives from southern African-Nordic research partnerships. Cape Town; Bellville: African Minds; The Southern African-Nordic Centre, 2017, p. 71-92. 
Recebido em 20/05/2019

Aprovado em 03/10/2019

Mateus de Oliveira Fornasier

E-mail: mateus.fornasier@gmail.com

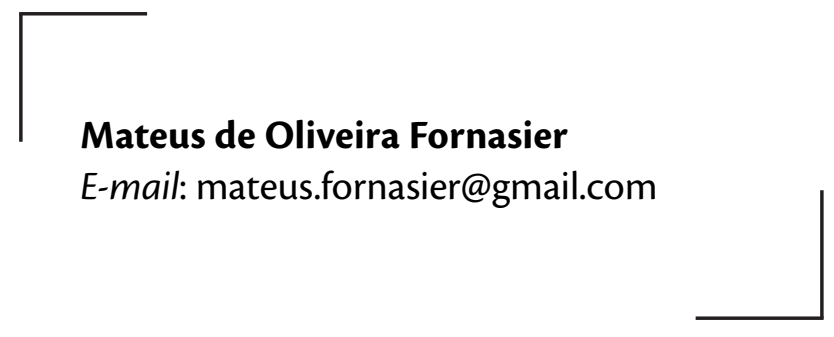

Sabine Franklin

E-mail: sifranklin61@gmail.com 